\title{
Authors in search of a character: ethnography and life writing
}

\section{Biography lost and found}

Not parallel but tangential: biography fits awkwardly with ethnography, doing well what ethnography does well to avoid. It cuts history to human shape, insinuates author into subject, and reads cause in sequence. Biographers enter the narrow circle of their subjects, dogging their footsteps, absorbed into their world often to the point of total identification. Their slow labours offer a point of view on the world, an exploration of the singular and subjective. All very different from classical ethnography, with its broader canvas and cultivated detachment, its two years in the field, its immersion in the here and now.

But ethnographers, no less than biographers, are shape-shifters; their trademark method, participant-observation, a transformation at once personal and professional. Fieldwork unfolds by acting and empathy, engagement and withdrawal. It's a process of shedding and reconstructing the self: a metamorphosis much analysed, sometimes embarrassingly recounted, but not often evoked with much conviction or depth (among exceptions, Abu-Lughod 1993, Briggs 1970, Gardner 1991, Jackson 1995, Read 1966, Willis 1999). Ethnography implies, but underuses, biography.

Perhaps it is missing a trick. In this article, I make the case for a more deliberate and fine-grained biographical engagement, not just in studies with a life-history focus but as a general principle, a principle of inclusion, where conventional reporting has worked by exclusion: the gutting and sorting required of standard ethnography. In recent years, opinion has tended the other way. If anything - the general view goes we have had too much of a good thing, an excess of the personal, crudely equated with the autobiographical. A stream of fin de siècle confessional ethnographies seemed to exemplify the vice of over-identification, where author displaces subject, cuckoo-like, and biography morphs into autobiography: the Lenin-and-me model. Even in the classics, objective to a fault, some critics detected the deforming personal note. In Works and Lives, Clifford Geertz (1988) revisited past masters and showed in each case how the Life possessed the Work, how ethnography amounted to little more than a sensibility on tour - an assessment disturbing and amusing in equal measure. If the tight-lipped functionalists, bent on witch beliefs and clan segmentation, were actually, in the cant of the day, 'writing themselves', giving voice to a certain world view - brittle, self-assured, knowledgeable - what of their less buttoned-up successors 
for whom objective knowledge was never a goal or even a possibility? Geertz's point was an extension of an old conceit. The style is the man is the ethnography. The greats prevailed because of powerful voices, not powerful theories.

To British anthropologists this seemed like elegant overkill. Yet at the end of his life Edmund Leach (1989) outbid Geertz and leapfrogged the postmodernists in declaring all ethnography to be autobiography. From Leach of all people the claim was baffling. Whatever its merits, Pul Eliya is to autobiography what the Phone Book is to poetry. Highland Burma, overflowing with theory, is sparsely populated. Leach's deathbed conversion contradicted his well-publicised shift from functionalism to structuralism, neither of which had much room for Others, let alone Self. So what lay behind the declaration? A good Durkheimian, Leach liked to see one thing as another: myth as ritual, ritual as social structure, Kiriwina as Planet Malinowksi. A refusal to take things at face value was the beginning of explanation, and the writing of ethnography was no different in this respect from its object. Pry between the lines and you find a self-portrait.

Geertz's insight - that personality is subsumed in style, not content - is both more subtle and more penetrating than Leach's genial debunking, though the lessons he draws may be equally misleading. In his discussion of the ethnographic vita he defines the problem of 'having to produce scientific texts from biographical experiences' as a literary one, a matter of rhetoric not rapport (Geertz 1988: 14). The mistake of the po-mo doubters was to dither over epistemology, when - as the most effective writers knew - credibility was all about words on the page. The fumbling biographical encounter was something to be overcome, not paraded in the text. Autobiography, in contrast, was what the author brought to the page, not to the field.

The studied impersonality of Geertzian interpretivism meant bracketing the biographical, an exclusive focus on the public forms of knowledge, on the cultural framing rather than the subjective qualia of experience, the flow of action, or the brush of reality. The method found its charter in the famous study of Balinese personhood (Geertz 1973). If native ideology figured persons as geometric abstractions - rotating titles, points in cycles, empty signifiers - why shouldn't the author write real people out of the script?

Geertz was by no means unusual in his formalism. An otherwise appreciative review of a very different kind of analysis concludes: 'We never learn how the exorcists integrate trance into their own lives or how the patients feel at the end of a 
ceremony. Real events are swallowed up in a sea of abstractions; [the author] manages to talk about "experience" in the virtual absence of persons, himself included' (Lambek 1985: 294). It's a perennial complaint with diverse theoretical justifications (Abu-Lughod 1994, Cohen 1994, Jackson 2005). Which is not to slight a rich vein of ethnographic biography going back to Oscar Lewis, Cora DuBois's Alorese psycho-biographies, and the 'as-told-to' memoirs of Native Americans like Black Elk and Sun Chief (Brandes 1979); not to mention numerous reflexive ethnographies and work on the fringes such as Agee's Let us now praise famous men (1941), John Berger's fictional accounts of the French peasantry, and, more recently, Ghosh's In an antique land - thickly inhabited narratives all. The point is not that biography of one kind or another is altogether lacking, but that its absence - or attenuated presence - weakens much mainstream ethnography and undermines theory. Indeed, as theories grow more dense and writing more opaque, anthropologists find new reasons for excluding the biographical: that the continuous self is an illusion; that people exist in pieces or as the invention of the moment; that selfhood is distributed or partible (the individual a bustling crowd); that fieldwork is impossible and ethnography a lie. Except in anecdote and exemplar, all too often, the human presence is as firmly suppressed as the ethnographer herself, the 'writing up' an orderly assault on the first-person pronoun.

But what untold stories lie hidden in that puritan act of self-abnegation? The brief, intense spell of fieldwork - vita brevis, a life in two years - yields a wealth of incidents and encounters, richly biographical but consistently ignored. 'Relevance' winnows out the idiosyncratic, the resistant to theory, the stubbornly human. The rise in long-term ethnography - the life coinciding with the work - makes the neglect of biography all the more egregious. Too often the return visit is no more than an excuse to try out new theories or fill in the gaps. We grow old with our informants but what do we make of it?

\section{Beyond the case history}

Two recent works by (as it happens) my Brunel colleagues buck the trend. Isak Niehaus's portrait of his fieldwork assistant, a teacher in the South African lowveld, offers a view of a world through a life. As he explains: 
The aim of this monograph is to explore how the biography of one South African can inform our understanding of witchcraft in contemporary South Africa. I seek to tell the story of how one teacher, Jimmy Mohale, experienced the broader changes taking place in the country from 1964 to 2005, and came to interpret the misfortunes he encountered and his fatal illness as resulting from his father's witchcraft (2012: 3).

This is not a biography in the usual sense, then, but a biographical ethnography or, perhaps better, ethnographic biography. Jimmy's story, gripping in itself, offers a perspective on processes of social change, community conflict, masculinity, violence and family breakdown. His testimony, set in italicized paragraphs and gleaned from countless conversations, traces his life history through thematic chapters ('Becoming a man', 'Seeking revenge'), culminating in his untimely death. Jimmy's growing conviction that he is the victim of his father's witchcraft - and not, as Niehaus believes, a casualty of AIDS - lends a tragic intensity to the final pages. For all its scholarly apparatus, Witchcraft and a life in the new South Africa packs an emotional punch. The book has the merits of high quality ethnography, but what sets it apart is the author's long-term familiarity with the setting and the intimate, erratic relationship he formed with his assistant over a span of 15 years. It is the record of a friendship through all its seasons. (Niehaus lists himself as one of the 'central characters'.) The author is present at many of Jimmy's big moments. He alone - besides family - is permitted access to the dying man. He even figures in Jimmy's self-penned obituary. But he is acutely aware of his double role. Visiting his friend for the last time, Niehaus asks if he can do anything for him and receives the reply, 'Sakkie, you cannot be both a player and a referee'. It's a new predicament for the anthropologist: 'As his biographer, I was a referee who merely had to observe the contest between them [the brothers] and his father' (177).

Troubling on a personal level, the professional approach is nonetheless confidently applied. The vividly circumstantial portions of Jimmy's story ('One morning [my father] beat my mother with a porridge stirrer. He hit her so hard that the stick broke and the metal wire stuck in her head' [35]), contrast with the cool interlaced commentary. When Jimmy makes the stunning admission, 'People around here know me as being dead. That is why I don't have to be seen. You are interviewing a dead person' (180), the anthropologist follows with: 
This statement points to the significance of engagement of social relations in the constitution of personhood. Jimmy did not merely see himself as wasting away physically. He was also concerned about the disrupted nature of his social relationships. He acknowledged the extreme importance of patrilineal kinship networks in providing protection against the witchcraft of outsiders and therapeutic assistance. (180)

These are necessary points, and it is difficult to see how else Niehaus could have conveyed them without recourse to full-dress narrative. The alternation could be jarring, but narrative ballast steadies the ship. In ethnography, size matters. The accumulation of detail; the deep personal knowledge acquired over many years; the compelling family intrigue; above all, the personal investment in a friendship through thick and thin, combine to give the story great power.

Before I left, Jimmy called together all the members of his therapy management group [the family carers], and told them always to regard me as their brother. He cried as I walked out of the door. I felt extremely humbled and distressed, but only cried late that evening. Despite our very intimate social ties, I could not share the conviction of witchcraft that united Jimmy and his siblings. My suspicion of AIDS seemed to have confirmed my status as a perennial outsider. (182)

James Staples' similar project, an ethnographic biography of his field assistant, Das a Tamil Brahmin and leprosy sufferer - is differently pitched. Narrative and dialogue are seamlessly joined, scholarly points mostly deferred to endnotes, chapters follow chronology. Staples' absorbing book could certainly be enjoyed by a general audience but he is aware of the risk of losing readers who expect explanation and theory, and he throws them a bone or two. Perhaps it's not anthropology, they might say. Perhaps, as I believe, it is worth the risk anyway, especially if we have got foreground and background, people and context, back to front and need to rediscover the real (Beatty 2010). Or perhaps - to our detriment - reading habits are harder to change than writing habits, and compromises must be made.

At any rate, Staples wants to get round the problem of formulaic life histories told merely to advance a theory or illustrate a pattern. He reconstructs Das's story by accompanying him on visits to his old haunts, getting his friend to talk in rackety train 
carriages and roadside coffee stalls, letting him choose what he finds important. Staples shows that a conventional presentation would exaggerate the centrality of leprosy in Das's life and underplay other factors such as caste, class and gender. Like Niehaus, he wants to affirm the general validity of his singular focus: 'although his is a deeply personal account, a life like no other, it also remains one that tells more generalisable truths' (xviii). But, as he demonstrates, the biographical approach necessarily inverts the significance of the particular and general:

Looked at through the prism of an individual life ... abstract categories like caste or religion morph into something else altogether. Caste, for Das, is not so much a constraining structure that ranks him alongside others, but more a quality that shapes his whole identity and his perspective on the world. It changes the way he moves, what he eats, what he does, how he sees others and how they see him. (2014: xviii)

It would be hard to finish either book without concluding that what biography brings to ethnography is not just humane detail but a credibility difficult to match in the standard format.

The deep biographical engagement that makes ethnography possible, and which Niehaus and Staples beautifully exemplify, does not often blossom in the published work of anthropologists. This is not a view widely shared or likely to be accepted for the simple reason that biography, in the broad sense of a historical concern with persons and lives, has so often been trivialised, formularised, or made ancillary to the research process: the stuff of anecdote, case history and confession. The preferred task is to 'theorise', that is, render into theoretical discourse, as if this were equal to understanding.

Which rather epitomises the problem I want to address: that anthropology's strength - its theoretical heft - is ethnography's weakness. That Leachian doubling, that extraneous reference, whether comparative, theoretical, or reflexive, is less an encompassing of the actual than an evasion. The tendency is to shun the primary social reality, seeing through it or past it to generalities, causes, and models. The details of interwoven lives, which mean everything to those concerned and ought to mean something to us, get screened out. ${ }^{1}$ Even those approaches which start with experience - embodiment, practice, phenomenology - too often bury it in abstraction, reaching beyond the immediate for something formal, pre-existent, platonic. In the standard ethnography, the obligation is to encapsulate, theorize and compare: 
operations that require a turning away, a fitting of the evidence to a different kind of story. The people in case studies are forced into awkward dialogue with people in other ethnographies, other lives and plots, as if Romeo suddenly found himself pushed up against Lady Macbeth. And because they are never merely themselves, they are never really anyone. Their ordinary lives - which are always uniquely ordinary - are rendered flat and generic.

Biography - better still, group biography, the interweaving of lives - is a corrective, a way back to the real; an attempt, in Updike's words, 'to give the mundane its beautiful due'. It offers ethnography an alternative path. Not parallel, but tangential.

\section{Whose life is it anyway?}

'A shilling life will give you all the facts,' wrote Auden in Who's Who, a poem that reflects on the mystery of private life. Sharing lives rather than merely reporting on them, the field worker has an advantage over the biographer, a view of what lies behind 'the facts'. On my reading at least, 'life writing' does not always do the best job of capturing life. We read a thick biography knowing that a few minutes' FaceTime might give us a sharper sense of its subject, if not a surer grip on the detail. Life writing gives us life in the other sense: the human career, the three-score-yearsand-ten. But voice, expression, manner and posture are unavailable to the historical biographer; so too are the unrecorded words, the practical ethics, and the angle on the world: whatever makes up the singular man or woman. This human muddle is how the world comes to us: not (at least, not directly) through symbols, structures or ontologies, still less through texts, interviews or disembodied words. Our primary material is the personal stuff, and we possess it in abundance. At what price do we ignore it?

I want to argue for a more purposive biographical approach that builds on fieldwork's underused resources. To the vivid Now that eludes the biographer, ethnography can add the backstory that is the biographer's stock-in-trade. To presence it can add depth. Indeed, without a grasp of character, history, and circumstance any account of human behaviour is stillborn. The constituents of meaning, the dynamic of emotions, and the unfolding of action are all biographical in shape and import (Beatty 2010, 2014). Without them we have only frames, scripts and abstract forces. 
The question is how far to mine the biographical seam; whether, indeed, the whole enterprise is culture-bound, ethnocentrically egocentric. In Britain we take an interest in biography for granted: the top-selling printed book of 2013 was a football manager's biography. In the era of the selfie, we have Masters degrees in biography, weekend retreats on life writing, even biographies of biographers. In rural Indonesia where I do fieldwork, until yesterday, the diary, the blog and the private self were non-existent. The terms for life do not correspond to the life-term.

In Nias, an island to the west of Sumatra, only ranking chiefs have a narratable career - a life measured out in quantities of pork and gold awarded at feasts. Nothing else really counts. And those without pigs or gold and an ability to transact them do not count either. In the scale of things they have no biography. As a great man (exceptionally a woman) rises through the ranks and wins titles, adding credit to the ledger, he ascends to ancestorhood and a life worth telling. To take his place in the pantheon he has to earn the right. Only a great life - a narrated life - merits an afterlife.

I had never suggested it to him (preferring indirection), but the ailing, cantankerous chief of Orahua had long promised me a definitive interview, a life history. 'It'll take a week, there were so many pigs, so many earth-slippery-withblood feasts,' he boasted, priming my disappointment while watching me slyly for whetted interest. He contrived to die unquestioned, as I knew he would. Nonetheless, I heard something like the biography he might have given me when I witnessed his deathbed speech, a statistical review of his achievements from cradle to freshly dug grave (Beatty 2015: 255-266). Before assembled clansmen and affines he gave an account of himself ahead of divine judgment, a proud reckoning, gasped out ounce by ounce. His narrative contained nothing of the drama of his accession as a youth, thirty years earlier (his father had spanned the pagan headhunting era). Nor did he mention the war with the South during the lawless 1950s in which he had led the defence of the village, the death in a smallpox epidemic of his wife and six children, the act of Christian repentance on the village square that followed, his remarriage and second family, his domination of rivals, his keeping the state at bay, or his formation as man who had lived through different eras. None of these things, which a biographer might fasten on, were mentioned and no oratorical advantage was taken. Strictly, there was no story at all, in the sense of a connected narrative, with events told and significance drawn. Instead, a bare catalogue of prestations - the 336 pigs slaughtered at his 
installation, divided among so many guests from such-and-such villages; the gifts and countergifts at his weddings; the prodigious sums raised in brideprice for his daughters; the grandiose titles won at this or that feast: Lord who Blankets the Earth, Guest at the Sun's Blowout.

But the audience expected no more or less. Alert to any error, his captious but respectful followers aired their grievances as required, reminding him of unpaid festive debts and alluding to the pigs corralled outside to pay off creditors. 'You are a bird in the treetops, soon to depart. We won't enumerate your sins against us,' said his deputy, proceeding to list his omissions while the dying man scowled and pointed feebly to the tethered herd outside. Without public acknowledgment his account could not be closed and he would not pass freely to the ancestral Valhalla.

The chief's oration was more than a vainglorious review of a career; it was a kind of settling up. In the right not to endorse their leader, those who do not count retain a hold over those who do, and they steal a little of the glory. Just as he is more than himself, as his titles proclaim, they are part of him, and they are diminished by his death. At his passing, the self-made man proves to be a collective product not a finite individual: an ancestor-in-the making, a link in an illustrious genealogy; but also a man of the people. Hence the paradox: the strivers and over-reachers who dominate the stage in Nias are conspicuous egoists, swaggerers and blusterers; but their story includes the 'little people' who have made them, like the 'great houses' (omo sebua) they occupy in which every pillar is sourced to kinsmen and exchange partners, each post with a story of its own: the front boles hauled from the forest by mothers' brothers; the ridge-pole placed by their wife-givers; the roofbeams by the scattered wife-takers. The chief's send-off was a reminder of his complex, corporate origin and his moral ties; his fading presence, lingering in those gasped last words, a transition into something purely public. The chief is dead. Long live the chief!

However egocentric and telegraphic, the chief’s résumé was about much more than himself. It was a history of relations, a snapshot of the whole, a microcosm, much like the 'great house' he left behind. It expressed the world as he found it and as it shaped him in turn; but it lived on and changed in the mouths of the living. For months after his death, stories circulated about the manner of his passing. Was it troubled or serene, as good form required? I was asked by outsiders - who depended on my not knowing enough to add spin - whether he had torn at his flesh in remorse for unpaid debts, just as I was asked who had cried at the funeral. 
Biography, in this broad sense, is an evolving, collective project. Perhaps the same could be said of any distinguished Life. But the special compass of fieldwork its intricate, tentacular reach - gives the lie to the accusation of narrow partiality, the 'shilling life' that is too readily taken to be the sum of what biography can add. Far from being antithetical, biography is complementary, even necessary, to ethnography.

\section{Shedding the self: against biography}

In rural Java - same country, yet a world away - the conspicuous self is not admired. Success in Nias would be failure in Java. For practitioners of Javanese mysticism, name and personality, mundane achievement, are mere distractions, the illusions of vanity. The life course is a series of metamorphoses, like those of an insect or plant, in which process is what matters and there is no beginning or end. The tree, the leaves, the fruit are concealed in the seed. The tree dies and sprouts again and somehow it is the same thing, over and over. The key to salvation is to lose oneself along the way; or rather to find one's true Self in the All, the current of life that animates the cosmos. For what gets reproduced is not the individual organism but Life (urip), equated with the immanent God (Gusti Allah). The named individual is just the bearer. Questions like 'Where in the cycle are you?' Or 'Who, in fact, are you?' are not important. The particular is dissolved in the universal. Likewise, in the microcosm $/ \mathrm{macrocosm}$ concept cherished in Javanese thinking, the universal is contained in the particular, the world in a grain of sand and eternity in an hour. As one confirmed agnostic said to me when I teased him about placing offerings for the dead: 'Well, you know, Andrew, the ancestors are in me or nowhere; there's nothing outside, no God above, no spirits below. But that dish of red and white porridge [= Mother and Father] brings it all to mind; I feel what I owe them and what makes me who I am.'

In the initiation rite for the Sangkan Paran sect, the candidate, wrapped in a funeral shroud, is asked: 'What manner of person are you?' The answer runs: 'I am a person of old who follows the rules of now'. It is a declaration of continuity, of selftranscendence, the 'person of old' being a reincarnation (not necessarily literal), the 'rules of now' being the eternal order of things. A person's spiritual biography is a matter of awakening to this path, discovering one's errors, and achieving urip utama, mati sampurna: 'flawless life, perfect death'.

As in other traditions, the ups and downs of the mystical journey tend to follow a certain narrative model, like the Christian's passage from sinner to saint, with moral 
crises, sloughs of despond, and dawns of renewal. At a session with Sangkan Paran leaders in a provincial city, I was prompted to ask the Secretary for his story, from his feckless early life as a rickshaw driver, through debt and moral squalor, to enlightenment and serenity (graced with unlooked-for prosperity as a jeweller). Such tales have a didactic aspect, but one that is secondary to the theme of achieved enlightenment. In Sangkan Paran and other 'Javanist' (kejawen) sects that extol the pre-Islamic elements in Javanese culture, the emphasis is on a practical mastery of the self, the ridding of impurities, rather than a theoretical grasp of doctrine. Practice makes perfect.

Paradoxically, then, a biography develops through the divesting of the worldly self. And this biography serves as a model, a parable for beginners. The Secretary's polished tale, told with animation as if for the first time, was echoed in other confession-like stories I heard at late-night gatherings in villages around Banyuwangi. At these companionable 'rubbings together' of like-minded Javanists, experiences of meditation and pilgrimage are 'reported back' and sifted for meaning; the hardships of a night in a cave, the temptations visited on the seeker, the visions vouchsafed, are compared and contrasted. The quest is solo, but the fruits are shared. 'What did you see?' they ask one another after a night under the stars. 'What were you given?'

The pilgrim soul acquires a history, a second life of strange experiences and epiphanies on the mystic path. From stories circulated among the villagers or alluded to over huddled coffees, I learned about past mystical encounters and meetings with remarkable spirits, including the adept's spirit double, conjured as a mirror image in the depths of solitude. The head of Sangkan Paran, a retired brigadier in Surabaya, told how he had once confronted Brawijaya, the last king of Hindu Java, at dawn in a graveyard after a night of meditation. As a hanger-on, I was sometimes incorporated in these stories. On a pilgrimage to a shrine in the forest of Alas Purwo (Primeval Forest), while some of our party rested on the shoreline, I wandered out alone in the shallows over a lava bed to look for starfish. 'Who were you talking to?' they asked when I came back. They had seen me with a spirit man on the horizon. Others, lost overnight, had been guided to safety by hermits - whether real or phantoms, no one could tell. Visions 'granted' in solitude, symbolic dreams under the tree of Siti Jenar (a heretical mystic), pockets that filled with fish when you waded into the lagoon: owning stories like these was 'proof' of engagement with the other world. 
Members of the sect - a quarter of the adult population of Bayu, the village in Banyuwangi on the eastern tip of Java where I lived - worked on their own spiritual biographies, knew those of their fellows, and acquired a group identity, a collective oral history that memorialised their first contacts with the founder-mystic, Joyokusumo, initiation under his tutelage, and their own peregrinations as they roamed the sacred landscape, retracing the steps of exiled princes, meditating in lonely grottoes and desolate groves, 'proving' the teachings. The language in which these events and personages are evoked is a tissue of allusion, wordplay, symbolism and numerology, a code that passes over the heads of orthodox Muslims and others 'outside', like the talk of adults among children (Beatty 2009). 'Do not enter if you don't understand', reads an inscription on the lintel of Joyokusumo's tomb.

Some of the ideas are common currency among ordinary villagers of a syncretist orientation, many of whom have a smattering of Javanist philosophy, and at one level they are familiar to everyone from the litanies of prayer-meals and the mantras recited at rituals and shadow plays, though the deeper meanings - pantheistic, even atheistic are not generally known or are carefully ignored by pious Muslims as part of a traditional pact of tolerance. To be understood, in any case, such ideas must be experienced, properly felt in the deepest centre of consciousness-feeling (rasa). By implication, the spiritual biography is esoteric, rather than private or secret, though in so far as it is attached to flesh-and-blood individuals - everyone knows that Uncle Slamet or Ma Tanem know deep things, are a source of wise counsel, and are unperturbed by ordinary dangers: evil spirits, black magic, accidents and nasty surprises, 'things outside'.

Among adepts, a word or allusion is enough to invoke the symbolic world, the world within; and upon entering, practical enquiry about persons and places becomes otiose. Joyokusumo (a pseudonym, like Sangkan Paran) was a historical figure in the regular sense, an aristocrat who had gone into exile, lived in the forest, and settled on the edge of a plantation, taking a wife, possibly having a child, and setting up as gurumystic in the 1950s. ('But I cannot teach you if you don't already know,' ran one of his disclaimers.) He died in 1956, and was buried by Bayu's oldest members, who were among his first followers. I have a handbook that contains his sayings, mostly Javanist philosophy in the tradition of Ronggowarsito, a poet-mystic of the $19^{\text {th }}$ century, a litany sung at gatherings, and two photographs of the man on facing pages, young and old, a tall, slim figure with Javanese turban and sarong. Such, at least, are 
the externals. Yet in discussion, Joyokusumo becomes a purely symbolic figure, a cipher for mystical truths. 'Look at the young photo,' they said. 'Compare the flat, even-fingered left hand - like a woman's parts - with the pointed right: a man, but male and female - as are you. Look at the young beside the old. He changed as the moon waxed and waned, now male, now female.'

When Joyokusumo first entered Alas Purwo - a forest of symbols - he peeled off his face to reveal a tiger. In one guise he is a were-tiger, in another, Diponegoro, rebel prince in the Java War of 1825 (the gown is among his relics), in yet another, an avatar of Siti Jenar and a line of preceptors, a genealogy whose terminus is the current cohort of initiates, the thirteenth and fourteenth 'grades'. When he died, his body shrank to a metre, say the men and women who washed the corpse ('We drank the water; not a drop touched the ground'). Two days after his burial, when they pushed an iron rod into the ground, it came up clean. He had vanished, moksa. Then they remembered what he had once told them: 'I shall appear to you one day as a beggar or a drifter'. So it was, some months later, when he visited a follower in Bayu. Tamad was hoeing his field when a thin figure in old-fashioned garb, turban askew, accosted him. 'What manner of man are you?' said the vagrant. 'I carried on hoeing and ignored him, puzzled by the question. Then he took a swig from my flask and asked again. When he had turned away, moving off at lightning speed, I recalled the initiation question - how could I have forgotten? I ran after him, but he had gone.'

A biography, in this perspective, has little to do with the untold history of a Javanese villager, a life in and out of poverty, marked by personal milestones and historical epochs: youthful scrapes, marriages and children, the hardships of Dutch rule and Japanese Occupation, the Independence war and post-war turmoil. Nor is it like the straight path of the orthodox pious - childhood Koranic classes, wanderings among rural seminaries, participation in a community of faithful, the zealous murder of communists, the pruning of pagan rituals, the first veils in the 1990s, the boom in the pilgrimage. Still less is it like the onwards and upwards chronicles of the local politicos and nationalists. The mystical account is altogether different, a kind of antibiography, circling and paradoxical, with a disappearing centre. What starts as parabolic overlay (the awakening, the deepening of consciousness) gradually displaces the flesh-and-blood individual altogether. Man or woman merges with symbol. 
A return to the field in 2011 found my old mentors and companions in terminal transition, retired from the daily round, withdrawn into their mystical personae. Warno, whom I had known for twenty years as a solid sceptic, an atheist-mystic who would sit patiently explaining the folly of the world (religions, to him, were worldly affairs, each a kind of political party; the pious were like people who 'bumped their heads on air and tripped over non-existent obstacles'), now spoke entirely in symbolic code. Recently widowed, he lived in a lean-to beside his daughter's house, scarcely bothering to eat. At night he slept outside on the verandah, an old tarp pulled up to his hat. I took a friend, a fellow-lodger of the headman, to meet him. A Protestant teacher curious about Javanism, the lodger was baffled at the blunt replies in rough dialect that seemed to rebuff his formal High Javanese questions or turned them inside out. 'It's not that he strays off-topic,' he complained. 'He cannot get off it. And I don't understand a word.' Was the old man pikun, senile? he suggested as we walked home, his notebook empty. But no, he was not; not if you knew the backstory, the places and puns and numerology; it still made sense. What no longer mattered to Warno was the ordinary world of getting and spending, the lies and chatter that made village life possible. While others prattled he fell back on sighs and headshakes, small talk inconceivable. When I joined him on the verandah each evening, he simply resumed wherever we were. Once, after the interruption of a bowl of noodles served by his daughter, he wiped his mouth and took up our conversation without missing a beat. 'So the meaning of...'

It was the same with another of my cronies, Suyit, now blind and dependent on his ancient wife, Ma Suyit. (She: 'I'm his eyes now.' He: 'She always was.') Fellow initiates, class of 1953, they lived alone in a dingy hut, their conversation a continuous mystical commentary, by turns affectionate and riddling, half private language, half Javanist jargon. 'Light a me cigarette, Andrew', said Suyit, grinning as he tapped my knee, 'and describe the picture on the matchbox. Is it red and white with a dark figure - a beggar - in the middle? Ah, no coincidence!' He too was pikun in the neighbours' eyes, but he had left them far behind. Ma Suyit laughed at the very idea.

Besides those who disclaim a conventional life history there are those who never attained the right to possess one. That section of the village who were affiliated to the Indonesian Communist Party (PKI) - peasant activists, land reformers, blacklisted 'troublemakers' - either died in the massacres of 1965-6 or their civil rights under the dictatorship that followed. Their story, unspeakable even today, is one of botched 
careers and blighted lives. In Bayu, it finds an inarticulate cry in the Barong, an allnight drama staged for weddings and circumcisions and for the annual Village Cleansing, when bad spirits are driven from the village. At the climax of the show, as dawn breaks, the Guardian Spirit in the form of a were-tiger possesses one of the troupe who rampages through the crowd in a tiger mask. As a boy, the tiger-man had seen his father cut down by anti-communist vigilantes. His possession is an escape, his night job a safe haven - a living if not a life. By a peculiar irony, the two dozen members of the Barong troupe are all from the pariah category of PKI fellow travellers. Inside the village their story cannot be told - the ghastly details of the killings can only be whispered, the moral reckoning has never come. But they have carved out a role as custodians of the guardian spirit; they hold the welfare of the village in their hands. Non-persons in way quite different from the mystics, they have found sanctuary on the stage in a painted forest of symbols, where ape-men and weretigers caper with princes and heavenly nymphs.

\section{Baggy monsters}

So does a mismatch between individuating narrative and selfless ideology disqualify the ethnographer? If the native disclaims a point of view, even an ego, should the ethnographer construct one on her behalf? ${ }^{2}$ Where does a life - temporally, spatially, relationally - begin and end? And does it ever have the unity and coherence that the biographer supposes? Or are we passengers through many lives, in fact and imagination, commuting between roles and fantasies, victims of the 'biographical illusion'?

Henry James remarked that 'really, universally, relations end nowhere, and the exquisite problem of the artist is eternally but to draw, by a geometry of his own, the circle within which they shall happily appear to do so' (Bayley 1968: 65). In their selective handling of the data, and especially in their modelling of causes and examples, ethnographies are, in this sense fictional, even - one thinks of The Nuergeometrically exquisite. As with James, the fiction is less in the conjuring of persons than in the artifice of closure. A successful ethnography creates the illusion of selfcontainment, with only the loose ends of footnotes poking through. John Bayley, in whose book on Tolstoy I found the James quotation, goes on to draw the contrast: 'Relations in War and Peace certainly do not stop anywhere, and yet Tolstoy is not evidently concerned to mount any kind of exquisite geometry on their behalf. So little 
do the relations of Pierre, with us and with his world, stop, that they may be said never to have started. So many of the important things of his life have taken place outside the action of the book, gigantic though it is' (ibid.). It is this sense of an unseen but suggested context - of the characters' hinterland, of the world going on beyond the page - that gives War and Peace what Bayley calls its 'extraordinary breadth of reality'. Tolstoy did not even think of it as a novel, but as something sui generis. For his antithesis, Henry James, War and Peace epitomized the sprawling, shapeless fiction of the $19^{\text {th }}$ century that offered not Art but Life. 'What,' he asked, 'do such large, loose, baggy monsters, with their queer elements of the accidental and the arbitrary, artistically mean?'

Although I admire the clean minimalism of The Nuer, as an ethnographer I'm for the baggy monsters. Those queer elements of the accidental and arbitrary cannot be put aside as aesthetically - or theoretically - inconvenient. They are the very stuff of life, not something to be tidied away. Verisimilitude in ethnography depends on the unpredictable and singular, not on the regular and general; and veracity depends on placing those elements in broader context without diminishing their quiddity. Part of that context will be folk biography or anti-biography. The interplay of self-creation and self-denial (or aspiration and circumstance) is intensely revealing. To see a man reckoning up his life as it fades visibly away is indeed a story worth telling. So too is the quest for spiritual refinement against a backdrop of poverty and stubborn survival - the assertion of Id when Ego seeks release. For this we need a bigger canvas than conventional ethnography allows; we need the accumulation, not reduction, of biographical detail.

The placing of lives within contexts, or contexts within lives, whether in biography, fiction or ethnography, calls to mind geometrical metaphors, as James indicates: narrative arcs, parallel lives, tangents, concentric circles, intersections, the life compass. It all suggests a Newtonian, even God-like, point of view, an inscribing of order on the haphazard. But the problem for ethnographers has always been that of knowing what to do with the unruly persons, events and idiosyncrasies that do not fit the pattern - what Malinowski called the imponderabilia. You can frame them in case studies, making the event structured, the adventitious predictable. (Case studies are like inoculations, a small painless dose of inactivated reality.) Or you can interlard analysis with evocative description, which makes for livelier reading but tends toward narrative cliché because it depends on shallowly rooted 'characters' and typifying 
selection. As ever, the interest is in the analysis; scene-setting merely sugars the pill. Or you can opt for what's called dialogue but is actually interview. Here the voice is authentic, but the prompted words lack the normal functionality of speech. It's the difference between seeing Tuhami in action, hobnobbing with his demons, and hearing the strangled voice from the couch (Crapanzano 1980).

So is there a way to integrate the actual with the theoretical that does not rely on typification, selection, descriptive sugar-coating, or secondary revision; a way to incorporate those irreducible particulars that give stimulus, shape and purpose to social action? Yes, and if it still seems like going off at a tangent, then perhaps we should look again at what we expect from ethnography, how we read as well as how we write. For only a fully-fledged narrative that respects biographical and dramatic complexity can answer our questions about the nature of action and emotion, letting us see the world instead of seeing through it. Perhaps Jimmy, Das, Warno and Suyit would agree.

Abu-Lughod, Lila. 1993. Writing women's worlds. Berkeley: University of California Press.

1991. Writing against culture. In Recapturing anthropology (ed.) R. Fox. Santa Fe: SAR Press.

Bayley, John. 1968. Tolstoy and the novel. London: Chatto and Windus. Beatty, Andrew. 2009. A shadow falls: in the heart of Java. London: Faber. 2010. How did it feel for you: emotion, narrative, and the limits of ethnography. American Anthropologist 112: 430-443. 2014. Anthropology and emotion. Journal of the Royal Anthropological Institute 20 (3): 545-563. 2015. After the ancestors: an anthropologist's story. Cambridge: Cambridge University Press.

Brandes, Stanley. 1979. Ethnographic autobiographies in American anthropology. Central issues in anthropology 1(2): 1-17.

Briggs, Jean. 1970. Never in anger. Cambridge, Mass.: Harvard University Press.

Cohen, Anthony. 1994. Self consciousness. London: Routledge.

Crapanzano, Vincent. 1980. Tuhami: portrait of a Moroccan. Chicago: Chicago University Press.

Gardner, Katy. 1991. Songs at the river's edge. London: Pluto Press. 
Geertz, Clifford. 1973. Person, time and conduct in Bali. In The Interpretation of Cultures. New York: Basic Books.

1988. Works and lives. Stanford: Stanford University Press.

Jackson, Michael. 1995. At home in the world. Durham, NC.: Duke University Press. 2005. Existential anthropology. Oxford: Berghahn.

Lambek, Michael. 1985. Ecstasy and Agony in Sri Lanka. Comparative Studies in Society and History 27: 291-303.

Leach, Edmund. 1989. Review of Geertz, Works and Lives. American Ethnologist 16: 137-141.

Niehaus, Isak. 2012. Witchcraft and a life in the new South Africa. Cambridge: Cambridge University Press.

Rapport, Nigel. 2012. Anyone': the cosmopolitan subject of anthropology. Oxford: Berghahn.

Read, Kenneth. 1965. The high valley. New York: Scribners.

Staples, James. 2014. Leprosy and a life in South India: Journeys with a Tamil Brahman. Lanham: Lexington Books.

Strawson, Galen. 2004. Against narrativity. Ratio XVII: 428-452.

Willis, Roy. 1999. Some spirits heal, others only dance. Oxford: Berg.

${ }^{1}$ Jackson's remedy is a focus on 'lived events' rather than biography, but his criticism is similar: 'a great deal of ethnographic writing uses selected details from lived events in order to justify an interpretation, and rarely is an event described so fully or entirely that we, the readers, may see for ourselves the wealth of meanings it contains' (2005: xxvii). Cohen 1994 and Rapport 2012, in contrast, fasten on the individual, the Anyone (Rapport) whose consciousness transcends social roles. I explore the existential drama of self, ethnographer and other in After the ancestors (Beatty 2015). ${ }^{2}$ A disclaimer not confined to the mystic east. Strawson's (2004) critique of narrativity is based on his notion of 'episodic self-experience' which would falsify the coherence of a narrated self. 